\title{
Manajemen Pola Asuh Anak dan Remaja Oleh TP-PKK
}

\section{Taufik Irfadat}

Sekolah Tinggi Ilmu Social dan Ilmu Politik (STISIP) Mbojo-Bima

email : taufikirfadat@gmail.com

Article History:
Received: 16 April 2021

Revised: 19 April 2021

Accepted: 16 Juni 2021
Kata Kunci: Manajemen, pola asuh, prestasi.

\section{Abstrak:}

Latar Belakang: Perkembangan dan tantangan dalam rumah tangga di Desa Monta Baru semakin meningkat, seiring dengan pesatnya pertumbuhan dan dinamika masyarakat semakin baik. Seorang anak dan remaja yang diasuh dilakukan dengan penuh kasih sayang sehingga dalam proses tumbuh kembangnya sangat dipengaruhi oleh lingkungan keluarga, dan setelah itu oleh lingkungan diluar keluarga, peran keluarga dalam pendidikan, sosialisasi, dan penanaman nilai kepada anak sangat besar. Fokus pada pengabdian ini yaitu bagaimana mengelola pola asuh anak dan remaja di Desa Monta Baru, adapun tujuan untuk mengetahui manajemen pola asuh anak dan remaja yang baik dan benar.

Metode: Metode pengabdian yang diaplikasi adalah tindak aksi (action research) dan pendampingan.

Hasil: Kegiatan pendampingan terdapat berbagai kendala, tantangan TP-PKK dan Pemerintah Desa serta lembaga lainnya. Tantangan yang dilalui dari membangun komunikasi, koordinasi, bersinergi, waktu dan tenaga, dan partisipasi. Terbukti dengan lomba pola asuh anak dan remaja (PAAR) Desa Monta Baru berhasil juara 1 tingkat kecamatan lambu, kemudian mewakili Kecamatan ditingkat Kabupaten dan berhasil juara 1, kemudian berkompetisi di tingkat provinsi dan berhasil juara 1 dan Desa Monta Baru berhasil juara V (lima) pada level Nasional.

\section{Abstract:}

Background: The development and challenges in households in Monta Baru Village are increasing, along with the rapid growth and dynamics of the community which are getting better. A child and adolescent who is cared for is done with great affection so that in the process of growth and development it is very much influenced by the family environment, and after that by the environment outside the family, the role of the family in education, socialization, and instilling value to children is very large. The focus on this service is how to manage the parenting style of children and adolescents in Monta Baru Village, as well as the aim of knowing the proper and correct management of parenting for children and adolescents. 
Keywords: Management, upbringing, achievement.
Methods: The service method applied is action research and mentoring.

Result: The assistance activities encountered various obstacles, challenges for the TP-PKK and the Village Government and other institutions. The challenges faced from building communication, coordination, synergy, time and energy, and participation. This was proven by the parenting competition for children and adolescents (PAAR), Monta Baru Village won 1st place at the Lambu sub-district, then represented the District at the Regency level and won 1st place, then competed at the provincial level and won 1st place and Monta Baru Village won 5th place at the national level.

\section{Pendahuluan}

Berdasarkan UU nomor 6 tahun 2014 tentang desa pasal 1 ayat 1 bahwa desa adalah desa dan desa adat atau yang disebut dengan nama lain, selanjutnya disebut desa adalah kesatuan masyarakat hukum yang memiliki batas wilayah yang berwenang untuk mengatur dan mengurus urusan pemerintahan, kepentingan masyarakat setempat berdasarkan prakarsa masyarakat, asal usul, dan/atau hak tradisional yang diakui dan dihormati dalam sistem Pemerintahan Negara Kesatuan Republik Indonesia. Perkembangan dan tantangan dalam rumah tangga semakin meningkat seiring dengan pesatnya pertumbuhan keluarga atau rumah tangga baru dan perkembangan ekonomi yang sering mengalami kontraksi (RI, 2014). Seorang anak dalam proses tumbuh kembangnya dipengaruhi oleh lingkungan keluarga, dan setelah itu oleh lingkungan diluar keluarga, peran keluarga dalam pendidikan, sosialisasi, dan penanaman nilai kepada anak sangat besar. Eli Rohaeli Badria dan Wedi Fitriana mengatakan bahwa keluarga kuat adalah keluarga yang dapat menciptakan generasi-generasi penerus yang berkualitas dan berkarakter kuat sehingga menjadi pelaku dikehidupan masyarakat (Badria \& Fitriana, 2018).

Menurut Ketua Pokja I TP-PKK Pusat Panji Mulyana mengatakan bahwa "tujuannya mendorong terwujudnya karakter keluarga yang berakhlak dan bermoral berdasarkan falsafah pancasila, yang dicirikan dengan watak dan perilaku anggota keluarga yang beriman dan bertakwa kepada Tuhan Yang Maha esa, berbudi luhur, bertoleransi, bergotong royong, dan cinta tanah air". Tidak hanya itu adanya program pola asuh anak dan remaja juga dirumuskan untuk mengatasi berbagai problem salah satunya kekerasan pada anak, kekerasan seksual, dan kekerasan dalam rumah tangga dan upaya meminimalisir anak dan remaja untuk mencoba dan menghindari narkoba dan jenis lainnya yang berbahaya bagi kesehatan. Sangat diperlukan atensi dan supervisi dari orang tua dan keluarga terhadap anak atau remaja yang sangat besar rasa ingin tahu atau mencoba sesuatu.

Keluarga memberikan dasar pembentukan tingkah laku, watak, moral, dan pendidikan anak. Mengasuh dan membesarkan anak berarti memelihara kehidupan, kesehatan, mendidik dengan penuh ketulusan dan cinta kasih. Peran orang tua dalam 
mengasuh anak dalam membimbing dengan penuh cinta dan kasih sayang dapat menjadikan anak atau remaja merasa diperhatikan terutama tentang pemenuhan pendidikan agar terhindar dari perilaku buruk, fokus pada pendidikan, mengikuti bimbingan belajar, dan mengurangi pernikahan di usia dini (Sudarto, 2020). Menurut Masni, 2017 mengatakan bahwa dorongan dari keluarga kepada anaknya salah satunya adalah dengan memberikan pendidikan yang terbaik sejak dini. Keluarga merupakan suatu kelompok yang menjadi bagian dalam masyarakat bertempat tinggal didesa maupun dikota, dalam kelaurga terdiri dari ayah, ibu dan anak-anak, salah satu yang berperan dalam membina kelaurga adalah ibu (Masni, 2017). Sebagai seorang wanita, ibu dituntut untuk mempunyai waktu yang lebih mengurus anak-anak dibandingkan dengan ayah. Sedangkan ayah merupakan tempat anak-anak hidup dan bergaul dengan orang dewasa yang memiliki peran dan pengaruh tertentu dalam pembentukan pribadi dan perilaku anak (Ayun, 2017). Pola asuh dapat didefinisikan sebagai pola interaksi antara anak dengan orang tua yang meliputi pemenuhan kebutuhan fisik (makan,minum dan lain-lain) dan kebutuhan psikologis (rasa aman, kasih sayang, dan lain-lain) serta sosialisasi norma-norma yang berlaku di dimasyarakat agar anak dapat hidup selaras dengan lingkungannya (Juliana, 2021).

Apalagi dimasa pandemi COVID-19 ini yang melanda global, yang menjadikan seseorang harus menjaga jarak dan mematuhi protokol kesehatan agar terhindar dari virus corona. Seperti yang dikatakan oleh ketua TP-PKK Provinsi NTB, HJ. Niken Saptarini Widyawati Zulkieflimansyah mengkampanyekan 10 Program Pokok PKK yang terkait langsung dengan dampak COVID-19 yaitu kesehatan dan pentingnya Pola Asuh Anak dan Remaja (PAAR) dan disiplin warga dalam menggunakan masker. Niken Saptarini Widyawati Zulkieflimansyah mengatakan bahwa "saya berharap adanya pandemic COVID-19 ini dapat dijadikan pelajaran bagi orang tua untuk lebih peduli dengan tetap patuhi protokol kesehatan dan menjaga pola asuh anak".

Program pokok TP-PKK Desa Monta Baru Kecamatan Lambu Kabupaten Bima, yaitu: P4 (pedoman, penghayatan, dan pengamalam pancasila). a) Gotong royong; $b$ ) Pangan; c) Sandan; d) Perumahan dan tata laksana rumah tangga; e) Pendidikan dan keterampilan; f) Kesehatan; $g$ ) Pengembangan kehidupan berkoperasi; h) Kelestarian lingkungan hidup; i) Perencanaan sehat. Adapun program pokok tim penggerak pemberdayaan kesejahteraan keluarga (TP-PKK) Desa Monta Baru Kecamatan Lambu Kabupaten Bima telah menjalankan program tersebut dengan baik. Sehingga dalam lomba pola asuh anak dan remaja (PAAR) Desa Monta Baru berhasil meriah juara 1 tingkat Kecamatan Lambu, kemudian mewakili Kecamatan Lambu dalam lomba PAAR tingkat Kabupaten dan berhasil meraih juara 1 tingkat Kabupaten Bima, kemudian mewakili Kabupaten Bima untuk berkompetisi di tingkat Provinsi dan berhasil juara 1 tingkat provinsi NTB dan tidak hanya demikian Desa Monta Baru telah berhasil meraih juara V (lima) atau harapan II pada level Nasional.

Beragam prestasi yang berhasil diperoleh dan mangharumkan nama Desa Monta Baru Kecamatan Lambu. Desa Monta Baru berhasil mengukir sejarah sebagai pelopor bagi desa-desa lain di Kabupaten Bima pada umumnya dan Kecamatan Lambu khususnya, meskipun usia Desa Monta Baru masih kecil yaitu IX (sembilan) tahun sejak 
pemekaran dari Desa Kaleo sejak tahun 2012, Desa Monta Baru berhasil mengungguli desa-desa lain. Adapun isu yang diangkat yaitu keberhasilan TP-PKK dan Pemerintah Desa Monta Baru serta lembaga lainnya dengan fokus manajemen pola asuh anak dan remaja di Desa Monta Baru, alasan peneliti memilih ini karena Desa Monta Baru Kecamatan Lambu telah berhasil meraih juara I ditingkat Kecamatan, Kabupaten, Provinsi dan juara V atau harapan II pada level Nasional. Perubahan yang terjadi yang terjadi yaitu keluarga atau orang tua anak dan remaja yang ada Desa Monta Baru dapat mempertahankan pola asuh yang baik dan mengedepankan cinta dan kasih sayang terhadap anak dan remaja. Adapun tujuan dari pengabdian ini yaitu untuk mengetahui strategi rumah tangga (orang tua), TP-PKK, dan Pemerintah Desa serta lembaga lainnya dalam menjalankan program pola asuh anak dan remaja.

Kekerasan dalam rumah tangga, Kekerasan Terhadap Anak, dan kekerasan dalam pacaran (Kekerasan dalam tiga tahun terakhir) tahun 2016 tidak ada kasus kemudian tahun 2017 terdapat 1 (satu) kasus yaitu Kekerasan dalam rumah tangga dan ditahun 2018 terdapat kasus yang bervariatif yaitu Kekerasan dalam rumah tangga 2 (dua) kasus, Kekerasan Terhadap Anak 1 (satu) kasus, dan kekerasan dalam pacaran 1 (satu) kasus. (TP-PKK Desa Monta Baru, 2019). Adapun Pernikahan Usia Dini tiga tahun terakhir (Tahun 2016, 2017, dan 2018) Desa Monta Baru tidak ada (TP-PPK, 2019). Dapat dikatakan bahwa Kekerasan dalam rumah tangga, Kekerasan Terhadap Anak, dan kekerasan dalam pacaran di Desa Monta Baru semakin menunjukkan adanya revitaliasi bahwa tingkat kasus kekerasan semakin menurun. Data diatas merupakan catatan kasus kekerasan selama 3 (tiga) tahun 2016, 2017, dan 2018 bahwa tingkat kekerasan semakin turun dan semakin membaik.

\section{Metode Pelaksanaan}

Sebelum dilakukan pengabdian tahapan yang telah dilewati yaitu perencanan yang matang dengan menyusun master plan agar kegiatan dapat dilakukan secara sistematis adapun yang menjadi subjek yaitu TP-PKK Desa Monta Baru, Pemerintah Desa Monta Baru, lembaga lainnya. Tempat pengabdian di Desa Mota Baru Lokus pengabdian yaitu di Desa Monta Baru Kecamatan Lambu Kabupaten Bima. Keterlibatan subjek pendampingan yaitu memberikan pendampingan berupa pemberian pemahaman tentang administratif dan korespondensi, kemudian metode yang dilakukan yaitu tindak aksi atau terlibat sebagai pendampingan. Tahapan yang dilakukan perencanaan dan pemantapan, analisis problem, formulasi kegiatan, pelaksanaan atau tindakan, evaluasi, dan keputusan. 


\section{Jurnal ABDI MERCUSUAR}

Vol. 01, No. 01, Mei, 2021, pp. 068 - 077

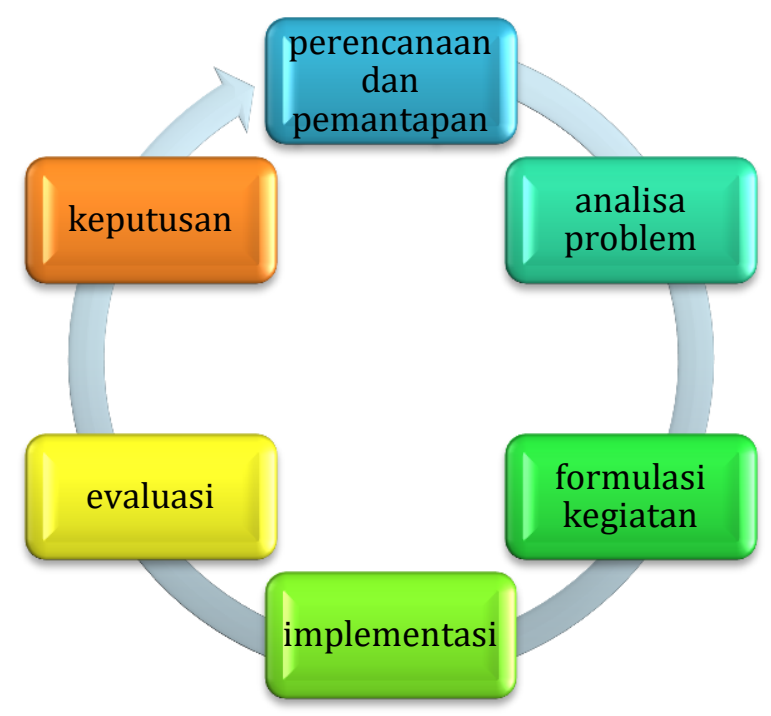

Gambar : 1. Road Map Kegiatan Persiapan Lomba PAAR Desa Monta Baru Kecamatan Lambu Kab. Bima

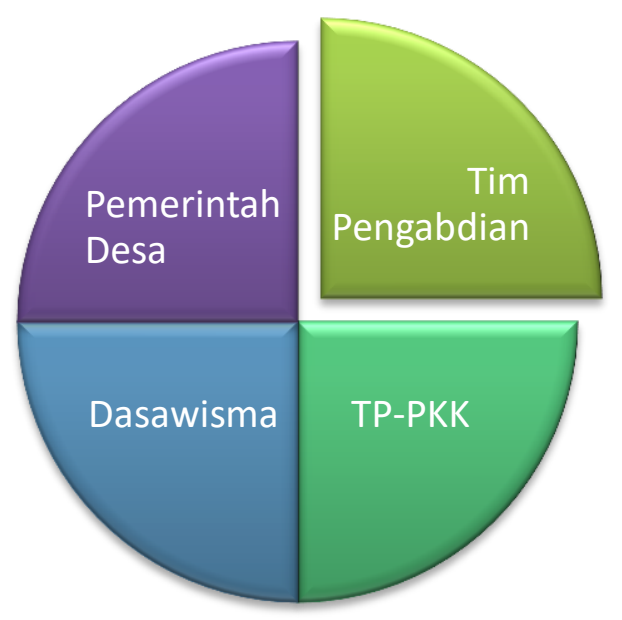

Sumber : TP-PKK Desa Monta Baru, 2019

\section{Hasil}

Dinamika kehidupan di Desa Monta Baru sangat baik meskipun usia Desa Monta Baru masih seumur jagung yang merupakan Desa pemekeran dari Desa Kaleo tetapi terdapat "harta karun" yang tersembunyi dengan beragam prestasi yang ditorehkan baik di tingkat Regional maupun dikancah Nasional. Desa Monta Baru bukan desa yang dianggap sepele melainkan sebagai desa pelopor bagi desa-desa lainnya di Kecamatan Lambu. Dalam implementasi kegiatan pendampingan terdapat berbagai kendala yang menjadi tantangan TP-PKK dan Pemerintah Desa serta lembaga lainnya. Tantangan yang dilalui mulai dari membangun komunikasi, koordinasi, bersinergi, waktu dan tenaga, dan partisipasi. Komunikasi, ini selalu menjadi persoalan yang akut yang dihadapi oleh semua orang terutama bagi TP-PKK dan Pemerintah Desa serta lembaga lainnya dalam mengkonstruktif interakasi yang intensif mengingat kegiatan PAAR ini sangat penting maka diperlukan interaksi semua anggota yang terlibat dalam menyelesaikan tugas masing-masing sesuai otorita. 
Koordinasi yang dibangun oleh TP-PKK dan Pemerintah Desa serta lembaga lainnya dalam melaksanakan PAAR ini sangat baik hal ini tervisualisasi dengan adanya pendampingan dari berbagai tingkatan salah satunya pada saat lomba PAAR tingkat Kecamatan Lambu, semua unsur-unsur yang terlibat dilibatkan secara totalitas bekerja ikhlas dengan visi "Membangun Monta Baru". Keterlibatan semua pihak menjadi contoh konkret bahwa tanggung jawab moral tidak hanya dimiliki oleh stakeholder tetapi masyarakat juga terlibat. Bersinergi, dalam kegiatan ini begitu terasa secara intuitif kerjasama semua pihak dalam mendukung PAAR ini, banyak asumsi bahwa membangun sinergi dalam berbagai kegiatan sangat susah dan banyak kendala yang dihadapi tetapi kenyataan secara faktual membuktikan bahwa sinergitas TP-PKK dan Pemerintah Desa serta lembaga lainnya sangat baik dan patut dihargai sebagai bentuk atensi dalam kegiatan.

Waktu dan tenaga yang dibutuhkan dalam pelaksanaan PAAR ini terbilang cukup dan tidak mendesak sehingga TP-PKK dan Pemerintah Desa serta lembaga lainnya dapat memanfaatkan secara optimal agar kekurangan dapat ditutupi dan kesalahan dapat diselesaikan dengan baik, waktu dan tenaga yang tercurahkan oleh TP-PKK dan Pemerintah Desa serta lembaga lainnya sangat besar sehingga pada saat pelaksanaan dapat melibatkan berbagai kalangan. Partisipasi yang ada di Desa Monta Baru sangat baik, hal ini terlihat dari partisipasi semua kalangan dalam menyukseskan PAAR ini, sifat gotong-royong masih terproteksi dengan baik sehingga dalam kegiatan dapat terlakasana sesuai jadwal. Dengan banyaknya kegiatan dan rutinitas masing-masing tentu menjadi kendala yang akan dihadapi tetapi kenyataan secara faktual hal ini tidak sama sekali mengganggu. Tetapi dengan visi dan misi yang sama bahwa Desa Monta Baru harus menang dalam berbagai kompetisi dan jenjang.

Hal ini terbukti dengan lomba pola asuh anak dan remaja (PAAR) Desa Monta Baru berhasil meriah juara 1 tingkat Kecamatan Lambu, kemudian mewakili Kecamatan Lambu dalam lomba PAAR tingkat Kabupaten dan berhasil meraih juara 1 tingkat Kabupaten Bima, kemudian mewakili Kabupaten Bima untuk berkompetisi di tingkat Provinsi dan berhasil juara 1 tingkat Provinsi NTB dan tidak hanya demikian Desa Monta Baru telah berhasil meraih juara V (lima) atau harapan II pada level Nasional. Adapun perubahan sosial yaitu sifat dan sikap gotong royong masyarakat Desa Monta Baru semakin erat dan baik, komunikasi yang terjalin semakin harmonis, kehidupan sosial semakin dinamis dan berkurangnya angka kekerasan dan tindakan kriminal lainnya di Desa Monta Baru. Lembaga-lembaga Desa semakin bersinergi dengan masyarakat dan kompak dalam menyelenggarakan tugas dan fungsi masing-masing. 


\section{Jurnal ABDI MERCUSUAR}

Vol. 01, No. 01, Mei, 2021, pp. 068 - 077

Tabel: 1. Kegiatan PAAR di Desa Monta Baru selama 3 (tiga) tahun

\begin{tabular}{|c|c|c|c|c|c|}
\hline No & $\begin{array}{l}\text { Jenis kegiatan } \\
\text { (Sosialisasi) }\end{array}$ & Narasumber & Tanggal & Tempat & $\begin{array}{c}\text { Jumlah } \\
\text { yang hadir }\end{array}$ \\
\hline 1 & $\begin{array}{l}\text { Membentuk } \\
\text { Forum Anak } \\
\text { Desa }\end{array}$ & $\begin{array}{l}\text { Bp. Paulus } \\
\text { Mujiran dari YKK } \\
\text { Soegiyapranata }\end{array}$ & $\begin{array}{l}10 \\
\text { Oktober } \\
2018 \\
\end{array}$ & $\begin{array}{l}\text { Balai Desa } \\
\text { Monta } \\
\text { Baru }\end{array}$ & 30 orang \\
\hline 2 & $\begin{array}{l}\text { Pelatihan } \\
\text { Mendongeng } \\
\text { Anak }\end{array}$ & $\begin{array}{l}\text { Azma Faizun } \\
\text { Izzati dari Guru } \\
\text { PAUD }\end{array}$ & $\begin{array}{l}27 \\
\text { Oktober } \\
2018 \\
\end{array}$ & $\begin{array}{l}\text { Balai Desa } \\
\text { Monta } \\
\text { Baru }\end{array}$ & 40 orang \\
\hline 3 & $\begin{array}{l}\text { Training } \\
\text { Gender (Kader } \\
\text { pendamping } \\
\text { anak SD) }\end{array}$ & $\begin{array}{l}\text { Dewi dari PPT } \\
\text { Cahaya Kasih }\end{array}$ & $\begin{array}{l}17 \\
\text { Desember } \\
2018\end{array}$ & $\begin{array}{l}\text { SDN Monta } \\
\text { Baru }\end{array}$ & 30 anak \\
\hline 4 & $\begin{array}{l}\text { Training } \\
\text { Gender (Kader } \\
\text { pendamping } \\
\text { anak SMP) }\end{array}$ & $\begin{array}{l}\text { Dewi dari PPT } \\
\text { Cahaya Kasih }\end{array}$ & $\begin{array}{l}24 \\
\text { Desember } \\
2018\end{array}$ & $\begin{array}{l}\text { SMPN } 1 \\
\text { Bima }\end{array}$ & 30 anak \\
\hline 5 & $\begin{array}{l}\text { Training } \\
\text { Gender (Kader } \\
\text { pendamping } \\
\text { anak SMA) }\end{array}$ & $\begin{array}{l}\text { Dewi dari PPT } \\
\text { Cahaya Kasih }\end{array}$ & $\begin{array}{l}24 \\
\text { Desember } \\
2018\end{array}$ & $\begin{array}{l}\text { SMAN } 6 \\
\text { Bima }\end{array}$ & 30 anak \\
\hline 6 & $\begin{array}{l}\text { Tentang Hak } \\
\text { Anak }\end{array}$ & $\begin{array}{l}\text { TP PKK Desa } \\
\text { (POKJA I) }\end{array}$ & $\begin{array}{l}07 \\
\text { Januari } \\
2019\end{array}$ & $\begin{array}{l}\text { Balai Desa } \\
\text { Monta } \\
\text { Baru }\end{array}$ & 50 anak \\
\hline
\end{tabular}

Sumber: TP-PKK desa monta baru, 2019

Tabel : 2. Perencanaan kegiatan pokja TP-PKK Tahun 2018

\begin{tabular}{|c|c|c|c|c|}
\hline NO & PROGRAM & PRIORITAS & KEGIATAN & $\begin{array}{l}\text { SASARAN } \\
\text { KEGIATAN }\end{array}$ \\
\hline \multirow{4}{*}{1} & \multirow{3}{*}{$\begin{array}{l}\text { Penghayatan } \\
\text { dan } \\
\text { pengamalan } \\
\text { pancasila }\end{array}$} & \multirow{3}{*}{$\begin{array}{l}\text { 1. Pembinaan } \\
\text { ketaqwaan } \\
\text { terhadap Tuhan } \\
\text { Yang Maha Esa }\end{array}$} & $\begin{array}{ll}\text { a. } & \text { Mengadakan } \\
\text { santapan rohani / } \\
\text { bimbingan mental }\end{array}$ & $\begin{array}{l}\text { TP PKK Desa } \\
\text { dan RW }\end{array}$ \\
\hline & & & $\begin{array}{l}\text { b. Mendata ulang } \\
\text { Kelompok } \\
\text { keagamaan muslim } \\
\text { / non muslim }\end{array}$ & $\begin{array}{l}\text { Kelompok } \\
\text { keagamaan }\end{array}$ \\
\hline & & & $\begin{array}{ll}\text { c. } & \text { Mengadakan dan } \\
\text { mengikuti pengajian } \\
\text { rutin di Balai Desa } \\
\text { Monta Baru }\end{array}$ & $\begin{array}{l}\text { Kelompok } \\
\text { Keagamaan } \\
(\mathrm{RT}, \mathrm{RW})\end{array}$ \\
\hline & & $\begin{array}{l}\text { 1. Pola Asuh } \\
\text { Anak (PPA) }\end{array}$ & $\begin{array}{l}\text { Mengaktifkan } \\
\text { kembali permainan } \\
\text { simulasi Pola Asuh } \\
\text { Anak dan Remaja } \\
\text { dengan cinta kasih } \\
\text { (PAAR) }\end{array}$ & PKK RW \\
\hline
\end{tabular}


Vol. 01, No. 01, Mei, 2021, pp. 068 - 077

\begin{tabular}{|c|c|c|c|}
\hline & \multirow[t]{5}{*}{$\begin{array}{l}\text { 2. Pendidikan } \\
\text { Anak dan } \\
\text { Remaja }\end{array}$} & $\begin{array}{ll}\text { a. } & \text { Mensosialisasikan } \\
& \text { PIK/R dan KDRT } \\
\text { bagi Remaja Serta } & \\
& \text { Pendataan BKR, } \\
& \text { NAPZA, HIV \& Aids }\end{array}$ & $\begin{array}{l}\text { OKK RW dan } \\
\text { Remaja }\end{array}$ \\
\hline & & $\begin{array}{l}\text { b. Sosialisasi Program } \\
\text { PKBN Bagi remaja }\end{array}$ & $\begin{array}{l}\text { RW dan } \\
\text { masyarakat }\end{array}$ \\
\hline & & $\begin{array}{ll}\text { c. } & \text { Sosialisasi Jam } \\
\text { Wajib Belajar bagi } \\
\text { Anak }\end{array}$ & $\begin{array}{l}\text { RW dan } \\
\text { Masyarakat }\end{array}$ \\
\hline & & $\begin{array}{ll}\text { d. } & \text { Sosialisasi } \\
& \text { Pencegahan } \\
& \text { Pernikahan Dini } \\
\end{array}$ & $\begin{array}{l}\text { Ibu, anak dan } \\
\text { Remaja }\end{array}$ \\
\hline & & $\begin{array}{l}\text { e. Sosialisasi Forum } \\
\text { Anak }\end{array}$ & Remaja \\
\hline & \multirow[t]{3}{*}{ 3. Kadarkum } & $\begin{array}{ll}\text { a. } & \text { Mengaktifkan } \\
\text { penyuluhan hukum } \\
\text { dengan metode } \\
\text { permainan ular } \\
\text { tangga } \\
\end{array}$ & $\begin{array}{l}\text { TP PKK Desa, } \\
\text { RW, RT dan } \\
\text { Remaja }\end{array}$ \\
\hline & & $\begin{array}{ll}\text { b. } & \text { Sosialisasi } \\
& \text { Administrasi } \\
& \text { Kependudukan } \\
\end{array}$ & \\
\hline & & $\begin{array}{l}\text { c. Jemput bola } \\
\text { pembuatan KIA, } \\
\text { Akta Kelahiran }\end{array}$ & Masyarakat \\
\hline & \multirow[t]{2}{*}{ 4. KDRT } & $\begin{array}{l}\text { a. Sosialisasi PKDRT } \\
\text { dan penanganan } \\
\text { KDRT, PKSTA, } \\
\text { Traficking } \\
\end{array}$ & Masyarakat \\
\hline & & $\begin{array}{l}\text { b. Menjaring data dan } \\
\text { informasi PKDRT }\end{array}$ & Kader Desa \\
\hline \multirow[t]{4}{*}{$\begin{array}{ll}2 & \text { Gotong } \\
& \text { Royong }\end{array}$} & \multirow[t]{3}{*}{$\begin{array}{l}\text { Peningkatan } \\
\text { gotong } \\
\text { royong dan } \\
\text { kesetiakawa } \\
\text { nan sosial } \\
\text { dalam semua } \\
\text { aspek } \\
\text { kehidupan }\end{array}$} & $\begin{array}{l}\text { a. } \text { Meningkatkan } \\
\text { kegiatan sosial dan } \\
\text { gotong royong } \\
\text { dengan } \\
\text { melaksanakan } \\
\text { kerja bakti di } \\
\text { masing-masing } \\
\text { wilayah }\end{array}$ & $\begin{array}{l}\text { TP PKK Desa } \\
\text { dan warga } \\
\text { masyarakat }\end{array}$ \\
\hline & & $\begin{array}{l}\text { b. Mengaktifkan } \\
\text { arisan }\end{array}$ & $\begin{array}{l}\text { TP PKK Desa } \\
\text { dan warga } \\
\text { masyarakat }\end{array}$ \\
\hline & & $\begin{array}{ll}\text { c. } & \text { Mengaktifkan } \\
\text { jimpitan Koran }\end{array}$ & $\begin{array}{l}\text { TP PKK Desa } \\
\text { dan RW }\end{array}$ \\
\hline & $\begin{array}{l}\text { 2. Kegiatan } \\
\text { Lansia }\end{array}$ & $\begin{array}{l}\text { Memberikan bantuan } \\
\text { atau model bagi lansia } \\
\text { produktif dan remaja }\end{array}$ & $\begin{array}{l}\text { TP PKK Desa } \\
\text { dan warga } \\
\text { masyarakat }\end{array}$ \\
\hline
\end{tabular}




\begin{tabular}{lll}
\hline 3. Bakti Sosial $\quad$ a. & Menghimpun & TP PKK \\
& jimpitan untuk & Kecamatan \\
& membantu para & dan Desa \\
& anggota yang kena & \\
& musibah atau sakit & \\
& dan GOTA & \\
\cline { 2 - 3 } & b. $\begin{array}{l}\text { Menghimpun } \\
\text { limbah minyak } \\
\text { goring sebagai } \\
\text { bank limbah }\end{array}$ & \\
\hline
\end{tabular}

Sumber: TP-PKK Desa Monta Baru, 2019

\section{Diskusi}

Temuan hasil pengabdian partisipasi, harmonisasi, koordinasi, partisipasi sikap terbuka dan ramah. Tingkat kekerasan pada anak hanya 1 (satu) kasus di tahun 2018 dan kekerasan dalam rumah tangga hanya 1 (satu) kasus di tahun 2017 dan 2 (dua) kasus di tahun 2018, hal ini berdasarkan pada table berikut:

Table: I. KDRT, KTA (Kekerasan Terhadap Anak), dan KDP (Kekerasan Dalam rumah tangga) tiga tahun terakhir

\begin{tabular}{cccc}
\hline Desa Monta Baru & Tahun 2016 & Tahun 2017 & Tahun 2018 \\
\hline KDRT & - & 1 & 2 \\
\hline KTA & - & - & 1 \\
\hline KDP & - & - & 1 \\
\hline
\end{tabular}

Sumber: (TP-PPK, 2019)

Adanya kasus yang menimpa masyarakat kategori masih tergolong relative kecil hal ini berdasarkan table diatas, peranan dari TP-PKK Desa Monta Baru sangat baik dalam manajemen pola asuh anak dan remaja. Perlu dukungan dari semua pihak agar kekerasan dalam rumah tangga dan kekerasan pada anak kecil dapat dikurangi atau dihilangkan di Desa Monta Baru Kecamatan Lambu.

Desa Monta Baru merupakan desa pemekaran dari Desa Kaleo Kecamatan Lambu ditahun 2012, meskipun Desa mekar dengan segala keterbatasan yang ada tidak menjadikan Desa Monta Baru terhegemoni oleh desa-desa lain. Tetapi Di Desa Monta Baru inilah lumbungnya prestasi yang diraih.

\section{Kesimpulan dan Saran}

Prestasi yang telah diraih merupakan bentuk kerja keras yang dilakukan oleh TP-PKK, Pemerintah Desa dan lembaga lannya, Hal terbukti dengan lomba pola asuh anak dan remaja (PAAR) Desa Monta Baru berhasil meriah juara 1 tingkat Kecamatan Lambu, kemudian mewakili Kecamatan Lambu dalam lomba PAAR tingkat Kabupaten dan berhasil meraih juara 1 tingkat Kabupaten Bima, kemudian mewakili Kabupaten 
Bima untuk berkompetisi di tingkat Provinsi dan berhasil juara 1 tingkat Provinsi NTB dan tidak hanya demikian Desa Monta Baru telah berhasil meraih juara V (lima) atau harapan II pada level Nasional.

Adapun saran yaitu TP-PKK, Pemerintah Desa dan lembaga lainnya harus mempertahankan prestasi yang telah diraih bahkan harus ditingkatkan lagi. Perlu ditingkatkan partisipasi dari semua kalangan, membangun koordinasi dengan lembaga lainnya agar mudah memperoleh informasi. Perlu di intensifkan komunikasi.

\section{Ucapan Terimakasih}

Atas nama pribadi penulis mengucapkan terimakasih yang sebesar-besarnya kepada semua pihak yang ada di Desa Monta Baru Kecamatan Lambu atas bantuannya selama penulis melakukan pengabdian. Terutama untuk TP-PKK dan Dasa Wisma Desa Monta Baru yang telah menerima penulis untuk menjadi bagian dari pelaksanaan kegiatan lomba PAAR sehingga TP-PKK Desa Monta Baru berhasil mencapai prestasi yang membanggakan hingga dikancah Nasional.

Ucapan terima kasih juga untuk Pemerintah Desa dan lembaga lainnya yang telah menerima penulis dengan hangat, dinamika dalam pelaksanaan program PAAR merupakan hal yang wajar dalam kehidupan social dan perbedaan pendapat mewarnai jalannya kegiatan dalam nuansa berdemokrasi.

\section{Daftar Referensi}

Ayun, Q. (2017). Pola Asuh Orang Tua dan Metode Pengasuhan dalam Membentuk Kepribadian Anak. Thufula.

Badria, E. R., \& Fitriana, W. (2018). Pola Asu Orang Tua dalam Pengembangan Potensi Anak melalui Homeshooling Di Kancil. Comm_edu Cendikia.

Juliana, S. \&. (2021). Kebijakan Pembinaan Kesejahteraan Keluarga (PPK) dalam Melaksanaan Kegiatan Pola Asuh dan Remaja Desa Jangkang kecamatan Bantan Kabubaten Bengkalis. Niara.

Masni, H. (2017). Peran Pola Demokrasi Orang Tua Terhadap Pengembangan Potensi Diri dan Kreativitas Mahasiswa. Jurnal Ilmiah Dikdya.

RI, K. P. (2014). UU Nomor 6.

Sudarto, A. \&. (2020). Pola Asuh Demokrasi Orang Tua dalam Pengembangan Potensi Diri dan Karakter Anak Usia Dini . Jurnal Ilmiah Ilmu Pendidikan.

TP-PPK. (2019). Laporan Tahunan TP-PPK Desa Montari Baru. 